\title{
УДК 669.295.055.018.62:621.791.05
}

\section{А. Е. КАПУСТЯН ${ }^{1}$, А. В. ОВЧИННИКОВ ${ }^{2 *}$, И. А. ВАКУЛЕНКО}

${ }^{1}$ Каф. «Оборудование и технологии сварочного производства», Запорожский национальный технический университет, ул. Жуковского, 64, Запорожье, Украина, 69096, тел. +38 (096) 25672 60, эл. почта aek@zntu.edu.ua, ORCID 0000-0002-8979-8076

${ }^{2 *}$ Каф. «Механика», Запорожский национальный технический университет, ул. Жуковского, 64, Запорожье, Украина, 69096, тел. +38 (061) 76983 62, эл. почта glotka87@ukr.net, ORCID 0000-0002-5649-1094

${ }^{3}$ Каф. «Технология материалов», Днепропетровский национальный университет железнодорожного транспорта имени академика В. Лазаряна, ул. Лазаряна, 2, Днепропетровск, Украина, 49010, тел. +38 (056) 3731556 , эл. почта dnuzt_texmat@ukr.net, ORCID 0000-0002-7353-1916

\section{ПОЛУЧЕНИЕ СВАРНЫХ ИЗДЕЛИЙ ИЗ СПЕЧЕННЫХ ТИТАНОВЫХ СПЛАВОВ}

Цель. Ограниченное применение деталей из порошковых титановых сплавов связано с трудностями получения длинномерных заготовок, деталей сложной формы и больших габаритов. Решить данные проблемы можно путем применения технологий сварочного производства. Для этого необходимо провести исследование структуры и механических свойств сварных соединений спеченных титановых сплавов, полученных сваркой оплавлением. Методика. В качестве исходного материала использовали промышленные порошки титана марки ПТ5-1. Формообразование заготовок, химический состав которых соответствовал сплаву ВТ1-0, проводили методом порошковой металлургии. Соединения получали путем сварки оплавлением без подогрева. Проводили микроструктурные исследования и механические испытания. Для сравнения результатов проводились исследования литого сплава ВТ1-0. Результаты. Получены образцы сварных соединений спеченных титановых заготовок из сплава ВТ1-0 методом стыковой сварки оплавлением. При сварке микроструктура основного металла, состоявшая из зерен $\alpha$-фазы размерами 40...70 мкм, трансформируется для сварного шва и зоны термического влияния (ЗТВ) в пластинчатое строение $\alpha$-фазы. Остаточные поры в сварном шве практически отсутствовали, в ЗТВ их размер составлял до 2 мкм при 30 мкм в основном металле. Достигаемый уровень механических свойств сварного соединения спеченных титановых сплавов соизмерим с основным металлом. Научная новизна. Обнаружены качественные изменения структуры и достигаемый комплекс свойств соединений спеченных титановых сплавов, сформированных в результате стыковой сварки оплавлением. Практическая значимость. Показана принципиальная возможность получения качественных соединений спеченных титановых сплавов методом сварки оплавлением. Это дает основание для более широкого применения спеченных титановых сплавов за счет получения длинномерных заготовок, соответствующих деформируемым прутковым полуфабрикатам.

Ключевые слова: титановые сплавы; порошковая металлургия; сварка; сварной шов; зона термического влияния; структура; механические свойства

\section{Введение}

Титановые сплавы являются конструкционным материалом для ряда отраслей промышленности [9, 17]. Широкое применение деталей из титановых сплавов сдерживает их высокая стоимость. Весомой составляющей стоимости изделия является технология его получения. С технологической точки зрения одним из наиболее рациональных и распространенных методов получения полуфабрикатов из титана является метод порошковой металлургии (ПМ) [4, $10,11]$. Существенный недостаток ПМ - невозможность получения длинномерных заготовок и сложной геометрии изделия. Технологии сварочного производства позволяют решить данную проблему путем получения монолитных соединений деталей небольших размеров и простой конфигурации [1]. Как правило, литой титан сваривают аргоннодуговым, электронно-лучевым, плазменным, электрошлаковым способами, под флюсом, лазерной термической технологией, сваркой давлением [7, 18, $21,22]$ и комбинацией данных способов [20]. Свариваемость порошковых титановых сплавов изучали в основном при аргоннодуговой и точечной сварке [8, 14]. Сварка давлением весьма перспективна $[6,12]$, в частности, стыковая сварка оплавлением. Данный метод, об- 
ладая преимуществами других способов сварки давлением (позволяет соединять заготовки значительной длины без присадочных материалов, без защиты зоны сварки газами и за более короткое время в сравнение со сваркой плавлением), позволяет соединять заготовки без ограничения формы сечения свариваемых деталей [13]. Свариваемость при стыковой сварке оплавлением определяется, в основном, распределением температуры в деталях, величиной и характером пластической деформации торцов при осадке, микрорельефом и температурой торцевых поверхностей [15]. Все эти параметры в случае сварки спеченных сплавов могут в широкой степени варьироваться от количества и размера пор, структуры сплава, загрязненности исходного материала (порошка) окислами и т.п. Качество сварного соединения в значительной мере будет зависеть от температурного цикла сварки, процесса структурных изменений в металле шва и зонах термического влияния (3ТВ) $[2,5,16,19$ ]. Использование материалов и сплавов в спеченном состоянии неизбежно приведет к корректировке используемых в настоящее время технологий сварки [3]. В связи с этим, для более широкого применения титана необходимо исследование свариваемости спеченных титановых сплавов стыковой сваркой оплавлением.

\section{Цель}

Цель работы - исследование структуры и механических свойств спеченных титановых сплавов после стыковой сварки оплавлением без подогрева для определения возможности получения качественных сварных соединений данным методом.

\section{Методика}

В качестве исходного материала использовали промышленные порошки титана марки ПТ5-1 (ТУ 14-10-026-98) и гидрида титана производства ГП «Государственный научно-исследовательский и проектный институт титана», ГП «Запорожский металлургический опытнопромышленный завод». Заготовки для прутка изготавливали методом порошковой металлургии, химический состав которых соответствовал сплаву ВТ1-0 (ГОСТ 19807-91). Формообразование заготовок $\varnothing 38$ мм, длиной $70 \ldots 80$ мм (рис. 1, a) проводили путем прессования на гидравлическом прессе с давлением 900 МПа. Спекание проводили в вакуумной печи СНВЭ-

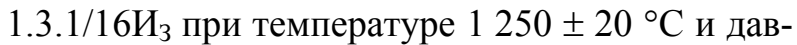
лении 13,3 Па в течении 3 ч. Охлаждение осуществляли с печью.

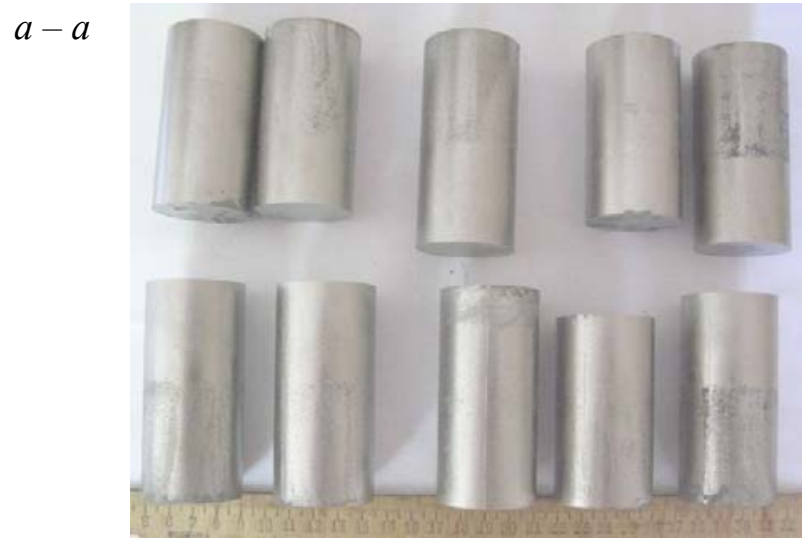

$\sigma-b$

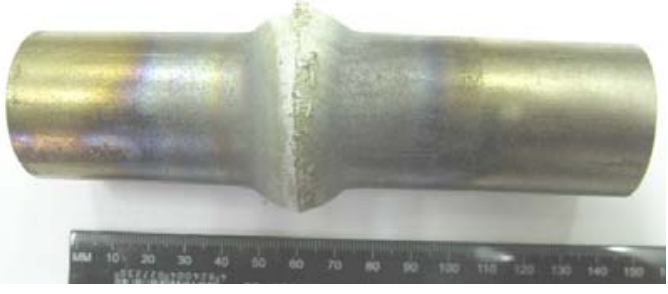

Рис. 1. Внешний вид опытных прессованных $(a)$ и сварных (б) заготовок

Fig. 1. The exterior of experimental nibs $(a)$ and welded $(b)$ blanks

Диаметр заготовок был выбран как предельный для сварки непрерывным оплавлением на обычных стыковых машинах без необходимости подогрева и применения защиты от воздуха (рис. 1, б).

Из рис. 1, б, по наличию цветов побежалости, определили размер ЗТВ, который составлял порядка 50 мм с каждой стороны шва. Учитывая известный эффект оттеснения электрического тока к поверхности, для используемого диаметра заготовок коэффициент поверхностного эффекта может быть более двух единиц [15]. На основании этого следует учитывать возможную разницу в эффективности разогрева поверхности и сердцевины заготовки при сварке, а, следовательно, и степени нагрева этих зон. Поэтому размеры ЗТВ дополнительно контролировали по изменению структуры заготовок.

Микроструктурные исследования осуществляли с использованием инвертированного мик-

(C) А. Е. Капустян, А. В. Овчинников, И. А. Вакуленко, 2014 
роскопа отраженного света «Observer.D1m». Механические испытания проводились в соответствие с требованиями ГОСТ 1497-84. Микротвердость образцов определяли на приборе ПМТ-3 при нагрузке 50 г.

Для сравнения полученных результатов проводились исследования литого сплава ВТ1-0.

\section{Результаты}

Фон травимости в основном металле матовый (рис. 2), в шве и ЗТВ с элементами блеска,

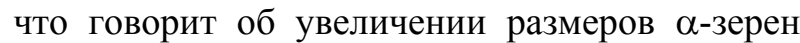
в результате перегрева при сварке: размеры макрозерен в сварном шве и ЗТВ составляли $2000 \ldots 3000$ мкм, в основном металле до 1000 мкм.

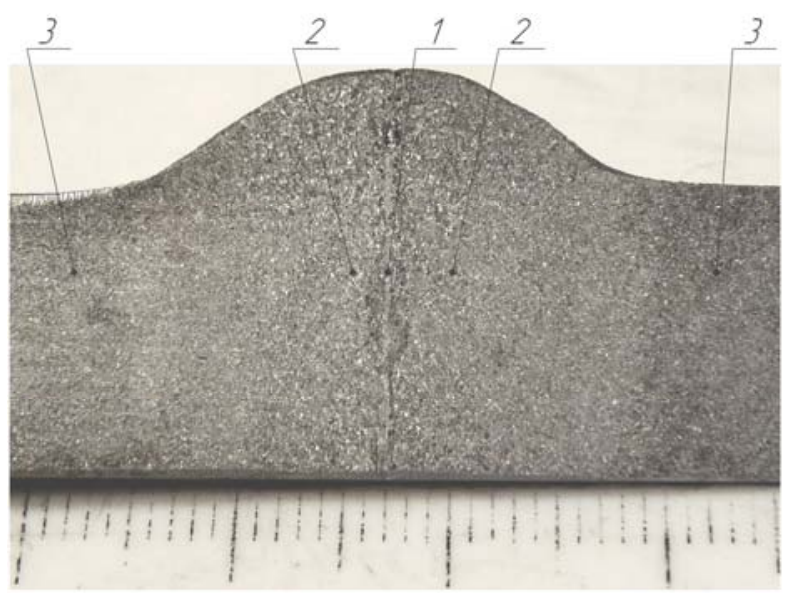

Рис. 2. Макроструктура сварной заготовки титана типа ВТ1-0, полученного методом ПМ:

1 - область сварного шва; 2 - 3ТВ; 3 - основной металл

Fig. 2. Macrostructure of a welded blank of titanium, type VT1-0, obtained by PM method:

1 - the seam weld area; 2 - HAZ; 3 - base metal

В результате количественной оценки параметров сварного соединения установлено, что ширина сварного шва находилась в пределах $250 \ldots 1750$ мкм, 3ТВ - 15...20 мм (рис. 2). При этом ЗТВ характеризовалась наличием $\beta$-превращенных колоний размерами $125 \ldots 205$ мкм (рис. 3). Такая структура характерна для сварных соединений литых титановых сплавов.

Микроструктура прессованных полуфабрикатов характеризовалась наличием зерен $\alpha$-фазы размерами 40...70 мкм, по границам которых располагались микропоры преимущественно сферической формы, диаметр которых составлял значение в пределах $6 \ldots 30$ мкм (рис. $4, a$ ).

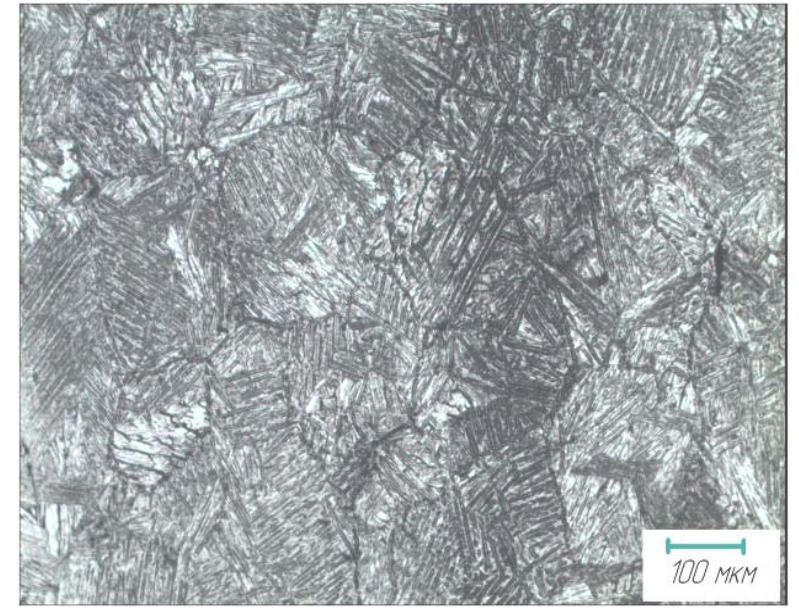

Рис. 3. Микроструктура сварного шва и ЗТВ соединения заготовок из опытного титана типа ВТ1-0, полученного методом ПМ

Fig. 3. Microstructure of the welding seam and HAZ of the blank joints from experimental titanium, type VT1-0, obtained using the method of powder metallurgy

Микроструктура ЗТВ сварного соединения (рис. 4, б) имела тонкопластинчатое строение, состояла из пачек параллельных $\alpha$-пластин с различной кристаллографической ориентировкой. Аналогичным, но более грубопластинчатым строением обладал шов (рис. 4, в). В металле шва пор практически не обнаружено. В ЗТВ поры носили единичный характер, до 2 мкм с преимущественным расположением по границам $\alpha$-пластин.

Механические испытания исследуемых сварных образцов позволили установить, что уровень их свойств соизмерим с уровнем свойств литого металла (табл. 1).

Таблица 1

Усредненные значения механических свойств образцов из титана

Table 1

Averaged values of the mechanical properties of samples from titanium

\begin{tabular}{l|c|c}
\hline \multirow{2}{*}{\multicolumn{1}{c|}{ Состояние }} & \multicolumn{2}{|c}{ Механические свойства } \\
\cline { 2 - 3 } & $\sigma_{\mathrm{B}}$, МПа & $\delta, \%$ \\
\hline Литой сплав ВТ1-0 & 365 & 10 \\
ПМ & 355 & 8 \\
ПМ после сварки & 355 & 8
\end{tabular}

( А. Е. Капустян, А. В. Овчинников, И. А. Вакуленко, 2014 


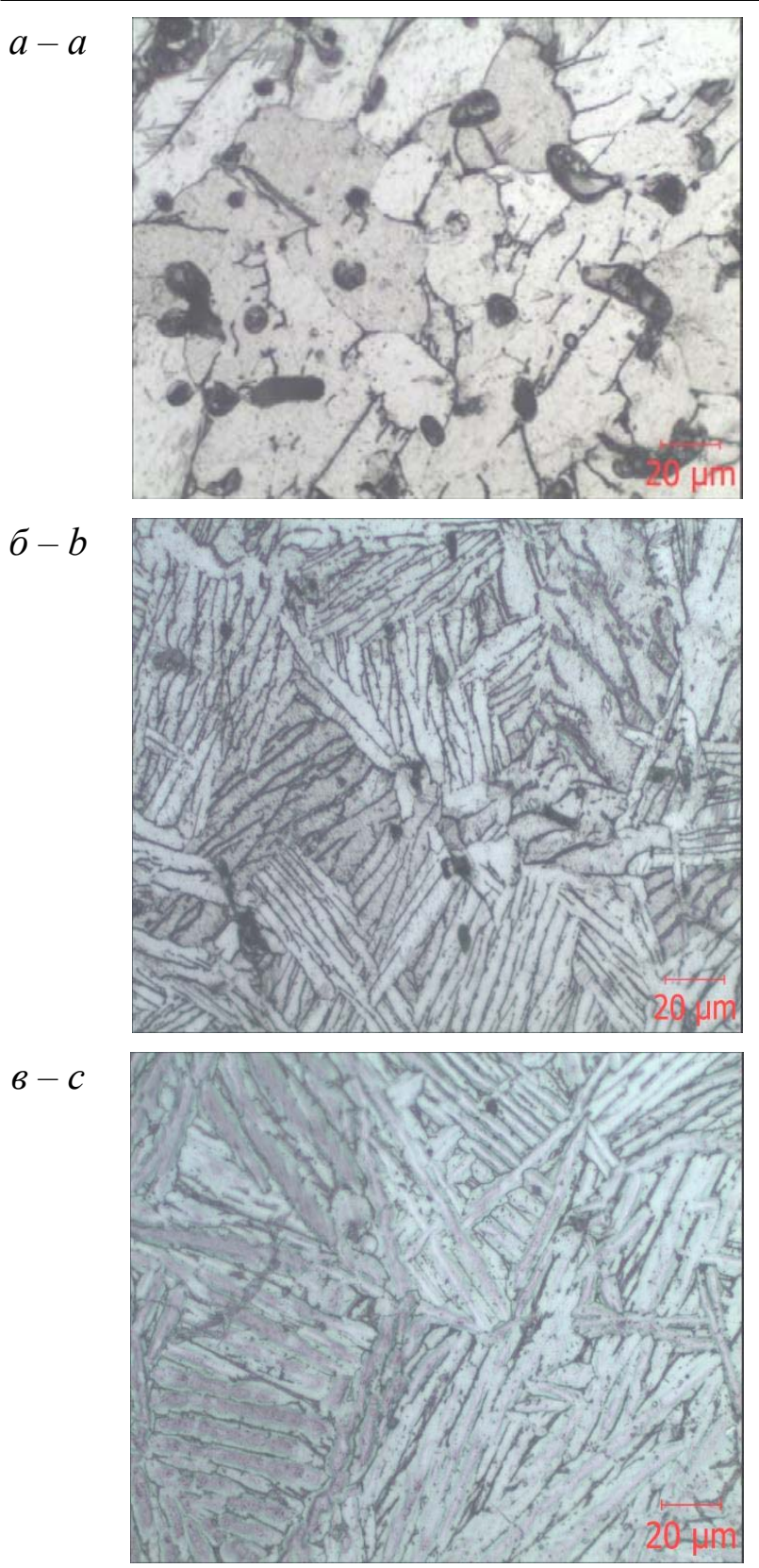

Рис. 4. Микроструктура основного металла (a), ЗТВ (б) и сварного шва (в) соединения заготовок из опытного титана типа ВТ1-0, полученного методом ПМ

Fig. 4. Microstructure of the basic metal $(a), \operatorname{HAZ}(b)$ and the welding seam $(c)$ of the blank joints from experimental titanium, type VT1-0, obtained using the method of powder metallurgy

Разрушение, в большинстве случаев, происходило в зоне, удаленной от сварного шва (рис. 5). Одной из причин такого разрушения является формирование металла повышенной плотности с дисперсной структурой в области сварного шва. Такое строение способствует повышению прочностных характеристик по сравнению с основным металлом спеченной заготовки. Таким образом, можно говорить о соизмеримости прочности сварного соединения с прочностью сплава ВТ1-0 в литом состоянии.

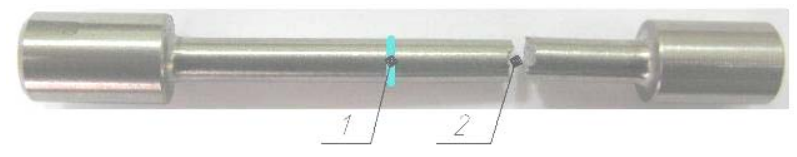

Рис. 5. Образец после испытаний на растяжение: 1 - сварной шов; 2 - место разрушения

Fig. 5. Sample after tensile tests: 1 - welding seam; 2 - position of fracture

Вместе с этим, неизменность микротвердости образцов $(2,5 \ldots 2,9$ ГПа) во всех зонах соединения указывает на необходимость проведения исследований по объяснению природы наблюдаемых явлений.

\section{Научная новизна и практическая значимость}

В настоящей работе обнаружены качественные изменения структуры и достигаемый комплекс свойств соединений спеченных титановых сплавов, сформированных в результате стыковой сварки оплавлением. Показана принципиальная возможность получения качественных сварных соединений при изготовлении из спеченных титановых сплавов длинномерных заготовок и изделий сложной конфигурации.

\section{Выводы}

1. Получены образцы сварных соединений из спеченных титановых заготовок сплава ВТ1-0 методом стыковой сварки оплавлением.

2. Металлографические исследования показали, что при сварке микроструктура основного металла, состоявшая из зерен $\alpha$-фазы размерами 40..70 мкм, трансформируется для сварного шва и 3ТВ в пластинчатое строение $\alpha$-фазы. Остаточные поры в сварном шве практически отсутствовали, в ЗТВ их размер составлял до 2 мкм при 30 мкм в основном металле.

3. Из анализа результатов испытаний на растяжение следует, что достигаемый уровень механических свойств сварного соединения спеченных титановых сплавов соизмерим с основным металлом.

(C) А. Е. Капустян, А. В. Овчинников, И. А. Вакуленко, 2014 


\section{СПИСОК ИСПОЛЬЗОВАННЫХ ИСТОЧНИКОВ}

1. Биковський, О. Г. Зварювання та різання кольорових металів : довідк. посіб. / О. Г. Биковський. - Запоріжжя : Видавець, 2011. - 390 с.

2. Вакуленко, І. О. Використання технології зварювання тертям 3 перемішуванням алюмінієвого сплаву / І. О. Вакуленко, С. О. Плітченко, Ю. Л. Надєждін // Вісн. Дніпропетр. нац. ун-ту залізн. трансп. ім. акад. В. Лазаряна. - Д., 2012. - Вип. 41. - С. 230-233.

3. Вакуленко, И. А. Технологии сварки с использованием различных источников энергии / И. А. Вакуленко, С. А. Плитченко // Вісн. Дніпропетр. нац. ун-ту залізн. трансп. ім. акад. В. Лазаряна. - Д., 2008. - Вип. 24. - С. 197-198.

4. Влияние водорода и легирующих элементов на особенности синтеза титановых сплавов с использованием гидрированного титана / О. М. Ивасишин, Д. Г. Саввакин, Н. М. Гуменяк, М. В. Матвийчук // Междунар. конф. Ті2011 в СНГ (25.04-28.04.2011) : сб. трудов. К. : РИО ИМФ им. Г. В. Курдюмова НАН Украины, 2011. - С. 322-328.

5. Иванов, А. П. Распределение температурных остаточных напряжений в швеллерах при нанесении сварного шва / А. П. Иванов, В. В. Псюк, И. А. Иванов // Вісн. Дніпропетр. нац. ун-ту залізн. трансп. ім. акад. В. Лазаряна. - Д., 2011. - Вип. 39. - С. 51-54.

6. Куликовский, Р. А. Определение прочности соединений титановых сплавов, выполненных сваркой трением / Р. А. Куликовский // Вестн. Донбас. гос. машиностроит. акад. - Краматорск, 2012. - № 3 (28). - С. 173-176.

7. Литвинов, А. П. Решение проблем сварки плавлением конструкций из титановых полуфабрикатов / А. П. Литвинов // Науч. вестн. ДГМА. - Краматорск, 2009. - № 1 (4Е). С. $123-128$.

8. Особенности сварки спеченных титановых материалов и свойства сварных элементов / В. М. Анохин, Р. К. Огнев, В. С. Попов, Г. Л. Дубров // Мат. соврем. техники : сб. науч. тр. / ППИ. - Пермь, 1975. - № 174. C. $151-154$.

9. Погрелюк, I. М. Забезпечення антикорозійного захисту і декоративного забарвлення деталям 3 титанових сплавів при хіміко-термічній обробці у контрольованому азотокисневмісному середовищі / I. М. Погрелюк, О. В. Ткачук, 3. О. Сірик // Вісн. Дніпропетр. нац. ун-ту залізн. трансп. ім. акад. В. Лазаряна. - Д., 2011. Вип. 38. - С. 220-224.
10. Применение гидрированного титана с заданным содержанием кислорода для получения изделий методом порошковой металлургии / И. О. Быков, А. В. Овчинников, С. И. Давыдов и др. / Теория и практика металлургии. - 2011. - № 1-2 (80-81). - С. 65-69.

11. Ресурсосберегающая технология получения длинномерных полуфабрикатов из титановых сплавов методом порошковой металлургии / А. В. Овчинников, А. Е. Капустян, В. Г. Шевченко и др. // Технологічні системи. - 2013. № 4 (65). - С. 29-33.

12. Сварка давлением при изготовлении сферических сосудов из титановых сплавов в состоянии сверхпластичности / Р. Я. Лутфуллин, А. А. Круглов, М. Х. Мухаметрахимов, О. Р. Валиахметов // Сварочное пр-во. - 2004. № 3. - C. 17-23.

13. Сварка трением : справ. / В. К. Лебедев, И. А. Черненко, Р. Михальски, В. И. Вилль. Л. : Машиностроение. Ленингр. отд-ние, 1987. $-236 \mathrm{c}$.

14. Скребцов, А. А. Исследование механических свойств сварных соединений спеченных титановых сплавов / А. А. Скребцов, А. В. Овчинников, А. Е. Капустян // Зб. наук. пр. «Вісн. СевНТУ». Сер. : Механіка, енергетика, екологія. - Севастополь, 2012. - Вип. 132. - С. 14-17.

15. Технология и оборудование контактной сварки / Б. Д. Орлов, Ю. В. Дмитриев, А. А. Чакалев и др. - М. : Машиностроение, 1975. - 536 с.

16. Формирование структуры металла шва титановых сплавов при электронно-лучевой сварке и сварке вольфрамовым электродом / В. И. Муравьев, Б. И. Дорлотов, П. Г. Демышев, Р. А. Физулакуов // Сварочное пр-во. - 2008. - № 7. C. 28-32.

17. Хорев, А. И. Высокопрочный титановый сплав ВТ23 и его применение в перспективных сварных и паяных конструкциях / А. И. Хорев // Сварочное пр-во. - 2008. - № 9. - С. 3-8.

18. Шабдинов, М. Л. Перспективные аспекты использования лазерной термической технологии для сварки и резки титановых сплавов / М. Л. Шабдинов, Г. М. Измаилова, Э. Ш. Джемилов // Вісн. Хмельниц. нац. ун-ту. - Хмельницьк, 2011. - № 5. - С. 31-34.

19. Electric pulse treatment of welded joint of aluminum alloy / I. A. Vakulenko, Yu. L. Nadezhdin, V. A. Sokirko et al. // Наука та прогрес трансп. Вісн. Дніпропетр. нац. ун-ту залізн. трансп. - 2013. - № 4 (46). - С. 73-82.

20. Fiber laser-GMA hybrid welding of commercially pure titanium / C. Li, K. Muneharua, S. Takao, H. Kouji // Mater. and Des. - 2009. - № 1. P. 109-114. 
21. Mathers, G. Job knowledge. Welding of titanium and its alaloys. Pt. 2 / G. Mathers // Connect : The Magazine and J. of TWI and the Welding and Joining Society. - 2011. - № 170. - P. 4-5.
22. Sutherlin, R. The welding of titanium and its alloys / R. Sutherlin // Weld. J. - 2007. - № 12. P. 40-45.

\section{О. Є. КАПУСТЯН ${ }^{1}$, О. В. ОВЧИННИКОВ ${ }^{2 *}$, І. О. ВАКУЛЕНКО ${ }^{3}$}

${ }^{1}$ Каф. «Обладнання та технології зварювального виробництва», Запорізький національний технічний університет, вул. Жуковського, 64, Запоріжжя, Україна, 69096, тел. +38 (096) 25672 60, ел. пошта aek@zntu.edu.ua, ORCID 0000-0002-8979-8076

$2^{*}$ Каф. «Механіка», Запорізький національний технічний університет, вул. Жуковського, 64, Запоріжжя, Україна, 69096, тел. +38 (061) 76983 62, ел. пошта glotka87@ukr.net, ORCID 0000-0002-5649-1094

${ }^{3}$ Каф. «Технологія матеріалів», Дніпропетровський національний університет залізничного транспорту імені академіка В. Лазаряна, вул. Лазаряна, 2, Дніпропетровськ, Україна, 49010, тел. +38 (056) 373 15 56, ел. пошта dnuzt_texmat@ukr.net, ORCID 0000-0002-7353-1916

\section{ОТРИМАННЯ ЗВАРНИХ ВИРОБІВ ЗІ СПЕЧЕНИХ ТИТАНОВИХ СПЛАВІВ}

Мета. Обмежене застосування деталей із порошкових титанових сплавів пов'язане 3 труднощами отримання довгомірних заготовок, деталей складної форми й великих габаритів. Вирішити дані проблеми можна шляхом застосування технологій зварювального виробництва. Для цього необхідно провести дослідження структури та механічних властивостей зварних з'єднань спечених титанових сплавів, отриманих зварюванням оплавленням. Методика. В якості вихідного матеріалу використовували промислові порошки титану марки ПТ5-1. Формоутворення заготовок, хімічний склад яких відповідав сплаву ВТ1-0, проводили методом порошкової металургії. Сполуки отримували шляхом зварювання оплавленням без підігріву. Проводили мікроструктурні дослідження та механічні випробування. Для порівняння результатів проводилися дослідження литого сплаву ВТ1-0. Результати. Отримано зразки зварних з'єднань спечених титанових заготовок зі сплаву ВТ1-0 методом стикового зварювання оплавленням. При зварюванні мікроструктура основного металу, що складалася із зерен $\alpha$-фази розмірами $40 . .70$ мкм, трансформується для зварного шва та зони термічного впливу (ЗТВ) у пластинчасту будову $\alpha$-фази. Залишкові пори в зварному шві практично були відсутні, у ЗТВ їх розмір становив до 2 мкм при 30 мкм в основному металі. Досяжний рівень механічних властивостей зварного з'єднання спечених титанових сплавів співмірний із основним металом. Наукова новизна. Виявлено якісні зміни структури та досяжний комплекс властивостей сполук спечених титанових сплавів, сформованих у результаті стикового зварювання оплавленням. Практична значимість. Показано принципову можливість отримання якісних сполук спечених титанових сплавів методом зварювання оплавленням. Це дає підставу для більш широкого застосування спечених титанових сплавів за рахунок отримання довгомірних заготовок відповідним прутковим напівфабрикатам, що деформуються.

Ключові слова: титанові сплави; порошкова металургія; зварювання; зварені шви; зони термічного впливу; структури; механічні властивості
A. YE. KAPUSTYAN ${ }^{1}$, A. V. OVCHINNIKOV ${ }^{2 *}$, I. A. VAKULENKO ${ }^{3}$
${ }^{1}$ Dep. «Equipment and Welding Technology», Zaporozhye National Technical University, Zhukovsky St., 64, Zaporozhye, Ukraine, 69096, tel. +38 (096) 25672 60, e-mail aek@zntu.edu.ua, ORCID 0000-0002-8979-8076
${ }^{2 *}$ Dep. «Mechanics», Zaporozhye National Technical University, Zhukovsky St., 64, Zaporozhye, Ukraine, 69096, tel. +38 (061) 76983 62, e-mail glotka87@ukr.net, ORCID 0000-0002-5649-1094
${ }^{3}$ Dep. «Materials Technology», Dnipropetrovsk National University of Railway Transport named after Academician V. Lazaryan, Lazaryan St., 2, Dnipropetrovsk, Ukraine, 49010, tel. +38 (056) 373 15 56, e-mail dnuzt_texmat@ukr.net, ORCID 0000-0002-7353-1916

\section{PRODUCTION OF WELDMENTS FROM SINTERED TITANIUM ALLOYS}

Purpose. Limited application of details from powder titanium alloys is connected with the difficulties in obtaining of long-length blanks, details of complex shape and large size. We can solve these problems by applying the

(C) А. Е. Капустян, А. В. Овчинников, И. А. Вакуленко, 2014 
welding production technology. For this it is necessary to conduct a research of the structure and mechanical properties of welded joints of sintered titanium alloys produced by flash welding. Methodology. Titanium industrial powders, type PT5-1 were used as original substance. Forming of blanks, whose chemical composition corresponded to BT1-0 alloy, was carried out using the powder metallurgy method. Compounds were obtained by flash welding without preheating. Microstructural investigations and mechanical tests were carried out. To compare the results investigations of BT1-0 cast alloy were conducted. Findings. Samples of welded joints of sintered titanium blanks from VT1-0 alloy using the flash butt welding method were obtained. During welding the microstructure of basic metal consisting of grains of an $\alpha$-phase, with sizes $40 \ldots 70 \mathrm{mkm}$, is transformed for the seam weld and HAZ into the lamellar structure of an $\alpha$-phase. The remaining pores in seam weld were practically absent; in the HAZ their size was up to $2 \mathrm{mkm}$, with $30 \mathrm{mkm}$ in the basic metal. Attainable level of mechanical properties of the welded joint in sintered titanium alloys is comparable to the basic metal. Originality. Structure qualitative changes and attainable property complex of compounds of sintered titanium alloys, formed as a result of flash butt welding were found out. Practical value. The principal possibility of high-quality compounds obtaining of sintered titanium alloys by flash welding is shown. This gives a basis for wider application of sintered titanium alloys due to long-length blanks production that are correspond to deformable strand semi finished product.

Keywords: titanium alloys; powder metallurgy; welding; welding seam; heat-affected zone; structure; mechanical properties

\section{REFERENCES}

1. Bykovskyi O.H. Zvariuvannia ta rizannia kolorovykh metaliv [Welding and cutting of non-ferrous metals]. Zaporizhzhia, Vydavets Publ., 2011. 390 p.

2. Vakulenko I.O., Plitchenko S.O, Nadezhdin Yu.L. Vykorystannia tekhnolohii zvariuvannia tertiam $\mathrm{z}$ peremishuvanniam aliuminiievoho splavu [Use of friction welding with aluminum alloy mixing]. Visnyk Dnipropetrovskoho natsionalnoho universytetu zaliznychnoho transportu imeni akademika V. Lazariana [Bulletin of Dnipropetrovsk National University of Railway Transport named after Academician V. Lazaryan], 2012, issue 41, pp. 230-233.

3. Vakulenko I.A., Plitchenko S.A. Tekhnologii svarki s ispolzovaniyem razlichnykh istochnikov energii [Welding technologies with the use of different energy sources]. Visnyk Dnipropetrovskoho natsionalnoho universytetu zaliznychnoho transportu imeni akademika V. Lazariana [Bulletin of Dnipropetrovsk National University of Railway Transport named after Academician V. Lazaryan], 2008, issue 24, pp. 197-198.

4. Ivasishin O.M., Savvakin D.G., Gumenyak N.M., Matviychuk M.V. Vliyaniye vodoroda i legiruyushchikh elementov na osobennosti sinteza titanovykh splavov s ispolzovaniyem gidrirovannogo titana [Effect of hydrogen and alloying elements on the characteristics of the synthesis of titanium alloys using hydrogenated titanium]. Sbornik trudov mezhdunarodnoy konferentsii «Ti-2011 v SNG» [Proc. of Int. Conf. «Ti-2011 in CIS»], Kyiv, 2011, pp. 322-328.

5. Ivanov A.P., Psyuk V.V., Ivanov I.A. Raspredeleniye temperaturnykh ostatochnykh napryazheniy $\mathrm{v}$ shvellerakh pri nanesenii svarnogo shva [Temperature distribution of residual stresses in channels under application of welding seam]. Visnyk Dnipropetrovskoho natsionalnoho universytetu zaliznychnoho transportu imeni akademika $V$. Lazariana [Bulletin of Dnipropetrovsk National University of Railway Transport named after Academician V. Lazaryan], 2011, issue 39, pp. 51-54.

6. Kulikovskiy R.A. Opredeleniye prochnosti soyedineniy titanovykh splavov, vypolnennykh svarkoy treniyem [Compound strength determination of titanium alloys, made by friction welding]. Vestnik Donbasskoy gosudarstvennoy mashinostroitelnoy akademii [Bulletin of Donbass State Engineering Academy], 2012, issue 3 (28), pp. 173-176.

7. Litvinov A.P. Resheniye problem svarki plavleniyem konstruktsiy iz titanovykh polufabrikatov [Solving the problems of fusion welding of titanium semi-finished constructions]. Nauchnyy Vestnik Donbasskoy gosudarstvennoy mashinostroitelnoy akademii [Scientific Bulletin of Donbass State Engineering Academy], 2009, no. 1 (4E), pp. 123-128.

8. Anokhin V.M., Ognev R.K., Popov V.S., Dubrov G.L. Osobennosti svarki spechennykh titanovykh materialov i svoystva svarnykh elementov [Features of welding sintered titanium materials and properties of welded elements]. Sbornik nauchnykh trudov Permskogo politekhnicheskogo instituta «Materialy sovremennoy tekhniki» [Proc. of Perm Polytechnic Institute «Materials of contemporary engineering»], 1975, no. 174, pp. 151-154.

9. Pohreliuk I.M., Tkachuk O.V., Siryk Z.O. Zabezpechennia antykoroziinoho zakhystu i dekoratyvnoho zabarvlennia detaliam $\mathrm{z}$ tytanovykh splaviv pry khimiko-termichnii obrobtsi $\mathrm{u}$ kontrolovanomu 
azotokysnevmisnomu seredovyshchi [Provision of anticorrosive protection and pattern coating of details from titanium alloys under chemical and heat treatment in a controlled nitrogen oxygen environment]. Visnyk Dnipropetrovskoho natsionalnoho universytetu zaliznychnoho transportu imeni akademika V. Lazariana [Bulletin of Dnipropetrovsk National University of Railway Transport named after Academician V. Lazaryan], 2011, issue 38, pp. 220-224.

10. Bykov I.O., Ovchinnikov A.V., Davydov S.I., Drozdenko M.V., Lekhovitser Z.V. Primeneniye gidrirovannogo titana s zadannym soderzhaniyem kisloroda dlya polucheniya izdeliy metodom poroshkovoy metallurgii [Application of hydrogenated titanium with a given content of oxygen to produce goods by powder metallurgy method]. Teoriya $i$ praktika metallurgii - Theory and Practice of Metallurgy, 2011, no. 1-2 (80-81), pp. 65-69.

11. Ovchinnikov A.V., Kapustyan A.Ye., Shevchenko V.G., Davydov S.I., Pavlov V.V. Resursosberegayushchaya tekhnologiya polucheniya dlinnomernykh polufabrikatov iz titanovykh splavov metodom poroshkovoy metallurgii [Alternative technology for manufacture of elongated semi-finished from titanium alloys by powder metallurgy method]. Tekhnolohichni systemy - Technological systems, 2013, no. 4, pp. 29-33.

12. Lutfullin R.Ya., Kruglov A.A., Mukhametrakhimov M.Kh., Valiakhmetov O.R. Svarka davlenieym pri izgotovlenii sfericheskikh sosudov iz titanovykh splavov v sostoyanii sverkhplastichnosti [Pressure welding in the spherical vessels manufacture from titanium alloys in a state of superplasticity]. Svarochnoye proizvodstvo - Welding production, 2004, no. 3, pp. 17-23.

13. Lebedev V.K., Chernenko I.A., Mikhalski R., Vill V.I. Svarka treniyem [Friction Welding]. Leningrad, Mechanical Engineering Publ., 1987. 236 p.

14. Skrebtsov A.A., Ovchinnikov A.V., Kapustyan A.Ye. Issledovaniye mekhanicheskikh svoystv svarnykh soyedineniy spechennykh titanovykh splavov [Mechanical properties investigation of welded joints of sintered titanium alloys]. Zbirnyk naukovykh prats «Visnyk SevNTU». Seriia: Mekhanika, enerhetyka, ekolohiia [Proc. of «SevNTU Bulletin». Series: Mechanics, Energy, Environment], 2012, issue 132, pp. 14-17.

15. Orlov B.D., Dmitriyev Yu.V., Chakalev A.A., Sidyakin V.A., Marchenko A.L. Tekhnologiya i oborudovaniye kontaktnoy svarki [Technology and equipment of resistance welding]. Moscow, Mechanical Engineering Publ., 1975. 536 p.

16. Muravyev V.I., Dorlotov B.I., Demyshev P.G., Fizulakuov R.A. Formirovaniye struktury metalla shva titanovykh splavov pri elektronno-luchevoy svarke i svarke volframovym elektrodom [Formation of weld metal structure of titanium alloys during electron beam welding and GTAW]. Svarochnoye proizvodstvo Welding production, 2008, no. 7, pp. 28-32.

17. Khorev A.I. Vysokoprochnyy titanovyy splav VT23 i yego primeneniye v perspektivnykh svarnykh i payanykh konstruktsiyakh [High-strength titanium alloy VT23 and its application in prospective welded and brazed designs]. Svarochnoye proizvodstvo - Welding production, 2008, no. 9, pp . 3-8.

18. Shabdinov M.L., Izmaylova G.M., Dzhemilov E.Sh. Perspektivnyye aspekty ispolzovaniya lazernoy termicheskoy tekhnologii dlya svarki i rezki titanovykh splavov [Promising aspects of laser thermal technology use for welding and cutting of titanium alloys]. Visnyk Khmelnytskoho natsionalnoho universytetu [Bulletin of Khmelnytsk Natioanl University], 2011, no. 5, pp. 31-34.

19. Vakulenko I.A., Nadezhdin Yu. L., Sokirko V.A., Volchok I.P., Mitiaev A.A. Electric pulse treatment of welded joint of aluminum. Nauka ta prohres transportu. Visnyk Dnipropetrovskoho natsionalnoho universytetu zaliznychnoho transportu - Science and Transport Progress. Bulletin of Dnipropetrovsk National University of Railway Transport, 2013, no. 46, pp. 73-82.

20. Li C., Muneharua K., Takao S., Kouji H. Fiber laser-GMA hybrid welding of commercially pure titanium. Mater. and Des, 2009, no. 1, pp. 109-114.

21. Mathers G. Job knowledge. Welding of titanium and its alloys. Pt 2. Connect: The Magazine and Journal of TWI and the Welding and Joining Society, 2011, no. 170, pp. 4-5.

22. Sutherlin R. The welding of titanium and its alloys. Weld. J, 2007, 86, no. 12, pp. 40-45.

Статья рекомендована к публикации д.т.н., проф. И. П. Волчком (Украина); д.т.н., проф. И. А. Вакуленко (Украина)

Поступила в редколлегию 14.03.2014

Принята к печати 28.04.2014 